\title{
On the spider fauna (Arachnida: Aranei) of the Katunsky Nature Biosphere State Reserve in South Siberia, Russia
}

\author{
О фауне пауков (Arachnida: Aranei) государственного \\ природного биосферного заповедника «Катунский»
}

\author{
L.A. Trilikauskas

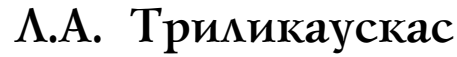

\begin{abstract}
Institute of Systematics and Ecology of Animals, Siberian Branch of the Russian Academy of Sciences, Frunze Str. 11, Novosibirsk 630091 Russia. E-mail: laimont@mail.ru.

Институт систематики и экологии животных СО РАН, ул. Фрунзе 11, Новосибирск 630091 Россия.
\end{abstract}

Key words: Araneae, list of species, spiders, fauna, Altai, Katunskii Reserve.

ключевые слова: Araneae, список видов, пауки, Алтай, Катунский заповедник.

Abstract. A check-list of 54 spider species from 41 genera and 12 families collected from the Katunsky Nature Reserve and the adjacent areas is given. 32 species are recorded from the reserve for the first time. Habitat and distribution data typical or each species in the studied area are provided. Currently, 129 spider species are known from Katunsky Reserve according to previously published data and the author's material presented in the paper. The families Linyphiidae (51 species) and Lycosidae (14 species) are the most rich in spider species recorded from the reserve. Presumptively, spider species diversity of the Katunsky Reserve is estimated about 300 species.

Резюме. Приведён список видов пауков, включающий 54 вида из 41 рода и 12 семейств, собранных на территории Катунского заповедника и у его границ. Из них 32 вида впервые отмечаются для территории заповедника. Для каждого вида дана информация о местообитаниях в районе исследований и его ареале. С учётом ранее опубликованных данных, для фауны Катунского заповедника к настоящему времени известно 129 видов пауков. Самым большим числом видов представлены семейства Linyphiidae (51 вид) и Lycosidae (14 видов). Прогнозируемое разнообразие фауны пауков Катунского заповедника оценивается не менее чем в 300 видов.

\section{Introduction}

Until the beginning of this century, published information on spider fauna of the Katunsky Reserve was rather fragmentary [Marusik et al., 1996, 2004]. Of the papers specifically devoted to araneofauna of this territory two short notes by N.V. Levina [Levina, 2002a, b] containing some general information on spiders of this reserve can be mentioned.

The first list containing 97 species recorded from the Katunsky Reserve was published in 2004 only [Levina, Mikhailov, 2004], in the paper devoted to spiders of the Mountain Altai. Later, identifications of twelve spider species mentioned in the latter paper were corrected by Tanasevitch [2013] in his comprehensive inventory of the Altai linyphiids. Thus, the spider fauna of this alpine and hard-to-reach reserve remains studied quite insufficiently.

The Katunsky Biosphere Reserve lies in the mountain Altai, near the borders of four countries: Russia, Kazakhstan, Mongolia and China. Administratively, it belongs to Ust-Koksinsky District of the Altai Republic. The territory of the reserve is part of the Central Altai physiographic province, including southern and, to a lesser extent, northern slopes of the Katunsky Mt. Ridge and northern slopes of the Listvyaga Mt. Ridge; the geographic coordinates: $49^{\circ} 28-56^{\prime} \mathrm{N}, 85^{\circ} 34^{\prime}-86^{\circ} 34^{\prime} \mathrm{E}$ [Yashina, Zateyev, 2008].

The aim of the present paper is to complement the available information on the spider fauna of the Katunsky Reserve with new data.

\section{Material and methods}

The material for the present study was collected by the author in the late June - early July 2018, mainly from the vicinity of Taimenye Lake, as well as during a short trip to the valley of Katun River near the mouth of Tikhaya River and close to the border of the reserve. The material was collected by means of pit-fall traps, sorting out plant detritus and hand collecting from the ground and plants. Taymenye Lake is located in the north-western part of the reserve at an altitude of about $1500 \mathrm{~m}$ a.s.l. The dark coniferous taiga predominates in the lake's vicinity. With the ascent into the mountains, it is replaced by larch taiga and subalpine meadows.

Distribution of most recorded species follows the World Spider Catalog [2019]. For some species of the families Lycosidae, Linyphiidae and Salticidae, the distribution information is borrowed from special works 
devoted to individual taxa. In such cases, the original source is referred to in the text. Each species recorded from the Katunsky Reserve for the first time is marked with an asterisk $(*)$.

Taxon nomenclature corresponds to that of the World Spider Catalog [2019]. The studied material is deposited in the collection of the Institute of Systematics and Ecology of Animals Siberian Branch Russian Academy of Science (curator G.N. Azarkina).

List of localities. In the following list of species, the section on the Material's contains numbers in square brackets corresponding to the locality in which sample was collected. Here is a list of all localities: 1 - Katun' River Valley, right bank near Tikhaya River mouth, 4941'02.4" N, 85³9'29.9" E, 24.06.2018; 2 - middle reaches of Kharyuzovka River, left bank, 49 48'53.656.0" N, 8547'41.9-42.2" E, 1652-1660 m a.s.1., 26.06.2.07.2018; 3 - NW shore of Taimenye Lake, $49^{\circ} 48^{\prime} 48.6-$ 49.8" N, 8547'52.6-54.5" E, 27.06.2018; 4 - shore of Taimenye Lake, near the cordon, $49^{\circ} 48^{\prime} 40.9-42.9^{\prime \prime} \mathrm{N}$, $85^{\circ} 47^{\prime} 57.2-57.6^{\prime \prime} \mathrm{E}$, sediment on the shore, 27.06.2018; 5 - flood-plain of the Khairyuzovka River near its mouth, 4948'36.9" N, 8547'56.6" E, 25.06-02.07.2018; 6 - SE shore of Taimenye Lake, $49^{\circ} 48^{\prime} 08.2^{\prime \prime} \mathrm{N}$, $85^{\circ} 48^{\prime} 00.5^{\prime \prime} \mathrm{E}, 25.06 .2018 ; 7$ - NWern slope near Taimenye Lake, $49^{\circ} 49^{\prime} 35.9^{\prime \prime} \mathrm{N}, 85^{\circ} 48^{\prime} 25.5^{\prime \prime} \mathrm{E}, 1745$ 1760 m a.s.1., 29.06.2018; $8-\mathrm{NW}$ shore of Taimenye Lake, 4949'51.9" N, 8549'27.8" E, 25.06.2018; 9-NW shore of Taimenye Lake, 4949'47.4" N, 8549'54.3" E, $30.06 .2018 ; 10$ - NW shore of Taimenye Lake, $49^{\circ} 49^{\prime} 57.5^{\prime \prime} \mathrm{N}, 85^{\circ} 50^{\prime} 24.2^{\prime \prime} \mathrm{E}, 28.06 .2018$.

\section{Results}

\section{Araneidae}

Aculepeira carbonarioides (Keyserling, 1892)

Material. $1+$ 으. 7 .

Habitats. Scree.

Distribution. Holarctic range.
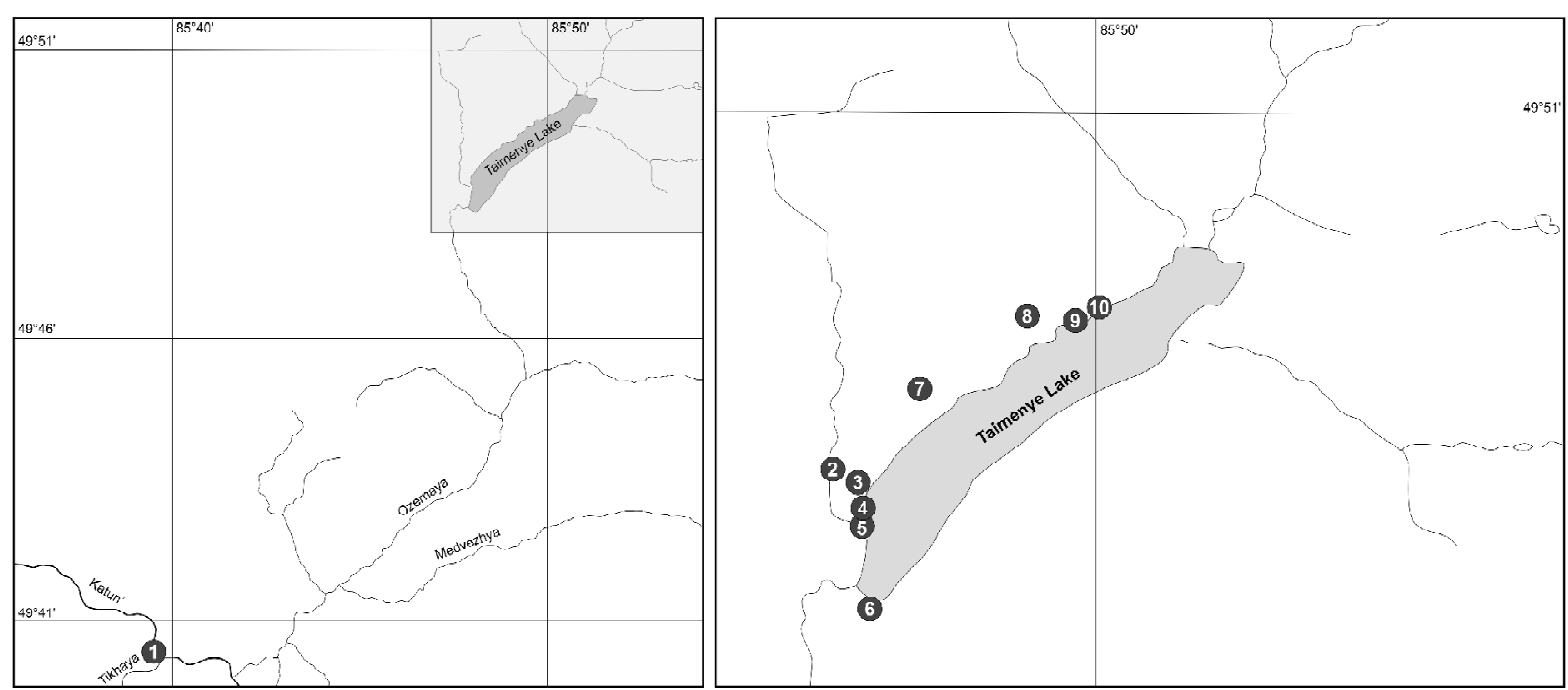

Material. 1 juvenile -2

Habitats. Dark coniferous forest, grass.

Distribution. Holarctic range.

Araniella displicata (Hentz, 1847)*

Material. 1 우 -4 .

Habitats. Wet meadow.

Distribution. Holarctic range.

Cyclosa conica (Pallas, 1772)*

Material. 1 juvenile -8 .

Habitats. Pinus sibirica-Abies sibirica forest, forest litter.

Distribution. Holarctic range.

Larinioides patagiatus (Clerck, 1758)

Material. $10^{7}, 2$

Habitats. Grass in floodplain.

Distribution. Holarctic range.

\section{Cheiracanthiidae}

Cheiracanthium erraticum (Walckenaer, 1802)*

Material. $10^{7}-2 ; 1$ 우 -3

Habitats. Grass meadow, sedge-grass meadow.

Distribution. Palaearctic range.

\section{Clubionidae}

Clubiona subsultans Thorell, 1875*

Material. $10^{7}-6$.

Habitats. Spruce-blueberry-green moss forest.

Distribution. Palaearctic range.

\section{Gnaphosidae}

Drassodes cupreus (Blackwall, 1834)

Material. $19-7$

Habitats. Scree.

Distribution. Palaearctic range.

Haplodrassus soerenseni (Strand, 1900)*

Material. $20^{7} \sigma^{7}-6$.

Habitats. Spruce-blueberry-green moss forest.

Distribution. Palaearctic range.

Fig. 1. Locality map of spiders.

Рис. 1. Точки сбора пауков. 


$$
\text { Micaria aenea Thorell, 1871* }
$$

Material. $19-2 ; 10^{\top}-4$.

Habitats. Grass meadow, sediment on the shore Distribution. Holarctic range.

Micaria pulicaria (Sundevall, 1831)*

Material. 1 우 -2 .

Habitats. Grass meadow.

Distribution. Holarctic range.

Zelotes fratris Chamberlin, 1920

Material. $10^{7}, 1+$ - 1.

Habitats. Grass meadow.

Distribution. Siberian-American range.

\section{Hahniidae}

Hahnia ononidum Simon, 1875

Material. 1 우 -3 .

Habitats. Sedge grass meadow.

Distribution. Holarctic range.

\section{Linyphiidae}

Agynetamollis (O. Pickard-Cambridge, 1871)*

Material. $50^{7} 0^{7}, 19-6$.

Habitats. Spruce-blueberry-green moss forest.

Distribution. Holarctic range.

Agyneta olivacea (Emerton, 1882)*

Material. $10^{x}-5 ; 40^{7} 0^{x}, 19-6$.

Habitats. Willow forest, spruce-blueberry-green moss forest.

Distribution. Holarctic range.

Anguliphantes sibiricus (Tanasevitch, 1986)*

Material. 1 우 -5

Habitats. Willow forest.

Distribution. West to South Siberia.

Bolyphantes distichus (Tanasevitch, 1986)*

Material. $20^{7} 0^{7}, 2$, 2 우 -10 .

Habitats. Near a snow patch in litter.

Distribution. Kazakhstan, West to South Siberia in Russia.

Centromerus clarus (L. Koch, 1879)

Material. $10^{7}-6 ; 1$ 우 -10

Habitats. Spruce-blueberry-green moss forest, near a snow patch in litter.

Distribution. Palaearctic range.

Gnathonarium taczanowskii

(O.Pickard-Cambridge, 1873)*

Material. 1 우 -9 .

Habitats. Stones near the mouth of stream on the bank of the lake.

Distribution. Holarctic range.

Hilaira herniosa (Thorell, 1875)

Material. 1 우 -6 .

Habitats. Spruce-blueberry-green moss forest.

Distribution. Holarctic range.

Hypselistesjacksoni (O.Pickard-Cambridge, 1902)*

Material. $20^{7} 0^{7}-5$.

Habitats. Willow forest.

Distribution. Palaearctic range.

\section{Lepthyphantes luteipes (L. Koch, 1879)*}

Material. 2 오 -3.

Habitats. Pine needles under Pinus sibirica in the forest. Distribution. East Palaearctic range.

Leptorhoptrum robustum (Westring, 1851)

Material. $19-10$

Habitats. Near a snow patch in litter.

Distribution. Holarctic range.

Oedothorax apicatus (Blackwall, 1850)*

Material. 1 우 -10 .

Habitats. Near a snow patch in litter.

Distribution. European - Ancient Mediterranean range [Tanasevitch, 2013].

Pityohyphantes phrygianus (C.L. Koch, 1836)*

Material. 1 우 -1 .

Habitats. Grass meadow.

Distribution. Palaearctic range.

Styloctetor compar (Westring, 1861)*

Material. $10^{7}-2$.

Habitats. Grass meadow.

Distribution. Holarctic range.

\section{Walckenaeria korobeinikovi Esyunin etEfimik, 1996*}

Material. $20^{7} 0^{7}-6$

Habitats. Spruce-blueberry-green moss forest. Distribution. Palaearctic range.

Zornella cultrigera (L. Koch, 1879)

Material. $20^{7} 0^{7}-6 ; 1$ 우 -10 .

Habitats. Spruce-blueberry-green moss forest, near a snow patch in litter.

Distribution. Holarctic range [Tanasevitch, 2013].

\section{Lycosidae}

Acantholycosa levinae

Marusik, Azarkina et Koponen, 2004

Material. $10^{7}-9$.

Habitats. Stones near the mouth of stream on the bank of the lake.

Distribution. Altai (Russia, South Siberia): Katunsky Mountain Ridge [Marusik et al., 2004].

Acantholycosa logunovi

Marusik, Azarkina et Koponen, 2004*

Material. 1 우 -9 .

Habitats. Stones near the mouth of stream on the bank of the lake.

Distribution. Altai (Russia, South Siberia): Chagan Uzun River canyon, Kuraiskii and Katunsky Mountain Ridges [Marusik et al., 2004; Fomichev et Marusik, 2011].

Acantholycosa norvegica (Thorell, 1872)

Material. $100^{7} 0^{7}$, 2 우 -6 .

Habitats. Spruce-blueberry-green moss forest.

Distribution. Palaearctic range.

$$
\text { Alopecosa aculeata (Clerck, 1758) }
$$

Material. $50^{7} 0^{7}-2 ; 1$ 우 $-4 ; 10^{7}, 1$ 우 $-5 ; 230^{7} 0^{7}$, 9우 -6 .

Habitats. Spruce-blueberry-green moss forest, grass meadow, dark coniferous forest, willow forest, wet meadow.

Distribution. Holarctic range. 
Alopecosa pulverulenta (Clerck, 1758)*

Material. $190^{7} 0^{\top}, 1+$ 우 $-2 ; 10^{\top}-4$.

Habitats. Grass and wet meadows.

Distribution. Palaearctic range.

Pardosa fulvipes (Collett, 1875)*

Material. $10^{7}, 1$, $1+-1 ; 290^{7} \sigma^{7}$, 6우우 -5 .

Habitats. Grass meadow, willow forest.

Distribution. West Palaearctic range.

Pardosa lasciva L. Koch, 1879

Material. $100^{7} 0^{7}$, 2 우 -6

Habitats. Spruce-blueberry-green moss forest.

Distribution. Palaearctic range.

Pardosa oksalai

Marusik, Hippa et Koponen, 1996

Material. $10^{7}-1 ; 40^{7} 0^{7}, 2+9+2 ; 1+9 ; 130^{7} 0^{7}$, 2 우 $-5 ; 10^{7}-9 ; 30^{7} 0^{7}, 2$, 99 - -10 .

Habitats. Grass meadow, willow forest, sediment on the shore, near a snow patch in litter, stones near the mouth of stream on the bank of the lake.

Distribution. West Palaearctic range.

Pardosa prativaga (L. Koch, 1870)*

Material. $30^{\top} 0^{7}, 3$, $39+-4$.

Habitats. Sediment on the shore of the lake.

Distribution. West Palaearctic range.

Pardosa sphagnicola (F. Dahl, 1908)

Material. 2우 - 4; $20^{7} 0^{7}, 19-6$.

Habitats. Sedge-sphagnum swamp.

Distribution. West Palaearctic range.

Trochosa terricola Thorell, 1856*

Material. 1 우 -2 .

Habitats. Grass meadow.

Distribution. Holarctic range.

Xerolycosa nemoralis (Westring, 1861)*

Material. $30^{7} 0^{7}, 2$ 우 - 2

Habitats. Grass meadow.

Distribution. Palaearctic range.

\section{Miturgidae}

Zora nemoralis (Blackwall, 1861)

Material. $19-8$

Habitats. Pinus sibirica-Abies sibirica forest, in litter.

Distribution. Palaearctic range.

\section{Salticidae}

Attulus avocator (O.Pickard-Cambridge, 1885)*

Material. $10^{7}-7$.

Habitats. Scree.

Distribution. East Palaearctic range.

Calositticusfloricola (C.L. Koch, 1837)

Material. $10^{\top}, 19-1 ; 10^{\top}-9$.

Habitats. Grass meadow, stones near the mouth of stream on the bank of the lake.

Distribution. Palaearctic range.

$$
\text { Evarchafalcata (Clerck, 1758) }
$$

Material. 1 우 $-3 ; 10^{7}-6$

Habitats. Spruce-blueberry-green moss forest, sedge grass meadow.
Distribution. Euro-Siberian range [Logunov et Marusik, 2000].

Heliophanus auratus C.L. Koch, 1835*

Material. $10^{7}-1 ; 20^{7} 0^{7}-9$.

Habitats. Grass meadow, stones near the mouth of stream on the bank of the lake.

Distribution. Euro-Siberio- Central Asian range [Logunov et Marusik, 2000].

Heliophanus patagiatus Thorell, 1875*

Material. $2+9$ - 7 .

Habitats. Scree.

Distribution. Palaearctic range.

\section{Sparassidae}

Micrommata virescens (Clerck, 1758)

Material. $19-2$.

Habitats. Grass in floodplain.

Distribution. Palaearctic range.

Theridiidae

Euryopis flavomaculata (C.L. Koch, 1836)*

Material. $10^{7}-2$.

Habitats. Grass meadow.

Distribution. Palaearctic range.

Parasteatoda tepidariuorum

(C.L. Koch, 1841)*

Material. $10^{7}, 19-1$.

Habitats. Grass meadow on stones.

Distribution. Cosmopolitan range.

\section{Thomisidae}

Ozyptila orientalis Kulczyñski, 1926*

Material. $10^{7}-3$.

Habitats. Sedge grass meadow.

Distribution. East Palaearctic range.

$$
\text { Ozyptila rauda Simon, } 1875
$$

Material. $19-2$.

Habitats. Edge of a dark coniferous forest.

Distribution. Palaearctic range.

$$
\text { Ozyptila trux (Blackwall, 1846)* }
$$

Material. $10^{7}-1$.

Habitats. Grass meadow.

Distribution. Palaearctic range (introduced to Canada).

Xysticus dzhungaricus Tystshenko, 1965*

Material. $10^{7}-3$.

Habitats. Sedge grass meadow.

Distribution. East Palaearctic range.

Xysticus luctuosus (Blackwall, 1836)

Material. $70^{7} 0^{7}, 19-2 ; 10^{7}-3 ; 10^{7}-5$.

Habitats. Willow forest, grass meadow, edge of a dark coniferous forest.

Distribution. Holarctic range.

\section{Conclusion}

The resulting list includes 54 spider species in 41 genera and 12 families, of which 32 species have been recorded from the reserve for the first time. Taking into 
account the previously published data [Levina, Mikhailov, 2004], a total of 129 spider species is known from the Katunsky Reserve now. The largest species number belongs to the families Linyphiidae (51 species) and Lycosidae (14 species). A real diversity of the spider fauna of the Katunsky reserve seems to be no less than 300 species.

\section{Aknowledgements}

The author is most grateful to the administration of the Katunsky Reserve and personally to the director, A.V. Zateyev, for their assistance in organizing and conducting work. The author is grateful to his colleagues Galina N. Azarkina (Novosibirsk, Russia) and Andrei V. Tanasevich (Moscow, Russia) for their kind help with the identification of Acantholycosa logunovi (Lycosidae) and Styloctetor compar (Linyphiidae) correspondingly. Galina N. Azarkina is thanked for help with preparation of the map. Special thanks go to Dmitri V. Logunov (Manchester, UK) for his kind linguistic help.

The study was supported by The Federal Fundamental Scientific Research Program for 2013-2020 (No. AAAAA16-116121410123-1).

\section{References}

Fomichev A.A., Marusik Yu.M. 2011. First description of the female of Acantholycosa logunovi (Araneae: Lycosidae) // Zootaxa. Vol.2813. P.65-68.

Levina N.V. 2002a. Analysis of spider communities in various biotopes of the Katunsky Reserve // G.S. Medvedev (Ed.)
Proceeding of the XII Congress of the Russian Entomological Society (Sankt-Peterburg, 19-24 august 2002). P.201. [In Russian].

Levina N.V. 2002b. The fauna and ecology of spiders in Katunskii State Reserve (Altai Mountains) // $20^{\text {th }}$ European Colloquium of Arachnology. Program. Abstracts. List of participans. Shombathely: Dept. of Zoology, Berzsenyi Dániel College; Budapest: Plant Protection Inst., Hungarian Acad. Sci. P.77.

Levina N.V., Mikhailov K.G. 2004. Spider (Aranei) Fauna of Mountainous Altai // Bulletin of Moscow Society of Naturalists. Vol.109. No.3. P.38-52. [In Russian].

Logunov D.V., Marusik Yu.M. 2000. Catalogue of the jumping spiders of northern Asia (Arachnida, Araneae, Salticidae). Moscow: KMK Sci. Press. Ltd. 299 p.

Marusik Yu.M., Hippa H., Koponen S. 1996. Spiders (Araneae) from Altai area, Southern Siberia // Acta Zoologica Fennica. Vol.201. P.11-45.

Marusik Yu.M., Azarkina G.N., Koponen S. 2004. A survey of East Palaearctic Lycosidae (Aranei). II. Genus Acantholycosa and related new genera // Arthropoda selecta. Vol.12 (for 2003). No.2. P.101-148.

Yashina T.V., Zateyev A.V. 2008. Realizatsiya printsipov ekosistmnogo podkhoda $\mathrm{v}$ Katunskom Biosphernom zapovednike // Zapovednoye delo. Nauchno-metodicheskiye zapiski komissii po sokhraneniyu biologicheskogo raznoobraziya (Sektsiya zapovednogo dela). Vol.13. M. P.99-111. [in Russian]

Tanasevitch A.V. 2013. The linyphiid spiders of the Altais, southern Siberia (Araeni: Linyphiidae) // Arthropoda selecta. Vol.22. No.3. P.267-306.

World Spider Catalog (2019). World Spider Catalog. Version 20.0. Natural History Museum Bern, online at http:// wsc.nmbe.ch (Accessed on 15 February 2019. doi: $10.24436 / 2$ 